\title{
First described fossil representatives of the parasitoid wasp taxa Asaphesinae n. n. and Eunotinae (Hymenoptera: Chalcidoidea: Pteromalidae sensu lato) from Eocene Baltic amber
}

\section{Roger A. Burks \& John M. Heraty}

To cite this article: Roger A. Burks \& John M. Heraty (2020) First described fossil representatives of the parasitoid wasp taxa Asaphesinae n. n. and Eunotinae (Hymenoptera: Chalcidoidea:

Pteromalidae sensu lato) from Eocene Baltic amber, Journal of Natural History, 54:9-12, 801-812, DOI: $10.1080 / 00222933.2020 .1747653$

To link to this article: https://doi.org/10.1080/00222933.2020.1747653

曲 Published online: 23 Sep 2020.

Submit your article to this journal $\asymp$

山ll Article views: 6

Q View related articles $\widetilde{ }$

View Crossmark data 


\section{First described fossil representatives of the parasitoid wasp taxa Asaphesinae n. n. and Eunotinae (Hymenoptera: Chalcidoidea: Pteromalidae sensu lato) from Eocene Baltic amber}

Roger A. Burks and John M. Heraty

Department of Entomology, University of California, Riverside, CA, USA

\begin{abstract}
New Baltic amber species of Pteromalidae sensu lato are described, from two different subfamilies, Asaphesinae n. n. and Eunotinae. Asaphesinae is provided as a replacement name for Asaphinae Ashmead 1904, which is a junior homonym of the trilobite family Asaphidae Burmeister 1843. Coriotela lasallei gen. n., sp. n.. and Butiokeras costae gen. n., sp. n.. are described as the first known fossil species of Asaphesinae and Eunotinae, respectively. These species establish the minimum known age of both groups in the Eocene. Taxonomic changes are also proposed for some extant species. The genus Desantisiana Neder de Román syn. $\mathbf{n}$.. is found to be a junior synonym of Notoglyptus, and its only described species is transferred as Notoglyptus jujuyensis (Neder de Román) comb. n.. The tribe Calyconotiscini, previously classified in Eunotinae, is abolished and Calyconotiscus Narendran \& Saleem is transferred to Pireninae.
\end{abstract}

\section{ARTICLE HISTORY}

Received 3 October 2019

Accepted 20 March 2020

Published online 23

September 2020

Published in print 23

September 2020

\section{KEYWORDS}

New species; Baltic amber; extinct

\section{Introduction}

Pteromalidae is well known as a polyphyletic 'dumping ground' of miscellaneous chalcidoid taxa (Noyes 1990; Gibson et al. 1999; Campbell et al. 2000; Krogmann and Vilhelmsen 2006; Munro et al. 2011; Heraty et al. 2013). No single molecular, morphological, or lifehistory trait can be used to reliably place species within Pteromalidae, and Pteromalidae has never been supported as monophyletic in any analysis that included more than one of its subfamilies (e.g. Munro et al. 2011; Heraty et al. 2013). However, we retain it in its current broad sense (sensu lato), in part because the phylogenetic relationships of most of its 31 subfamilies (Noyes 2019) are uncertain; they may be better combined to form a few distinct families, or may be better classified in other already existing families, but only after a thorough and robust revision of the family classification of Chalcidoidea.

Because higher-level classification of Pteromalidae imparts little information on how a group is distinct from and related to other chalcidoids, there is also little value in placing fossil taxa to Pteromalidae without further comment. Placing these taxa to subfamily or 
tribe communicates far more relevant information for Chalcidoidea (Burks et al. 2018). The discovery of fossil taxa also provides a better context for investigating the age of pteromalid subgroups.

Recently described verifiable Baltic amber chalcidoid taxa include fossil species from otherwise extant genera such as Metapelma Westwood (Eupelmidae: Neanastatinae) (Gibson 2009), Perilampus Latreille (Perilampidae) (Heraty and Darling 2009), Borneomymar Huber (Mymaridae) (Engel et al. 2013), Centrodora Förster (Aphelnidae), Mirufens Girault, Pterandrophysalis Novicky, and Szelenyia Novicky (Trichogrammatidae) (Burks et al. 2015). New Baltic amber genera have been described from Neanastatinae (Eupelmidae) and Tanaostigmatidae (Gibson 2008, 2009), Psilocharitini (Eucharitidae) (Heraty and Darling 2009), Aphelinidae, Trichogrammatidae (Burks et al. 2015), and Cerocephalinae and Herbertiinae (Pteromalidae sensu lato) (Bläser et al. 2015; Burks et al. 2018). Herein we describe the first known fossil species from two groups of Pteromalidae sensu lato, Asaphesinae and Eunotini (Eunotinae), from Baltic amber of the Kaliningrad region, placing the minimum known age of these lineages at 36.7-48.5 million years ago (Ritzkowski 1997).

Knowing the minimum age of these lineages provides a valuable calibration point for chalcidoid phylogenetics, and it may shed light on the evolution of the host associations of the lineages. Asaphesinae includes four genera, two that are associates of Hemiptera, and two Australasian genera that are egg parasitoids of Chrysomelidae. Species of Asaphes Walker are known primarily as hyperparasitoids attacking a variety of hosts in aphids, although some may be primary parasitoids of aphids or psyllids (see discussion in Gibson and Vikberg 1998). Hyperimerus Girault has been reared from psyllids (Bouček and Rasplus 1991). Ausasaphes Bouček and Enoggera Girault include endemic Australasian species that are egg parasitoids in Chrysomelidae, including the phoretic species Ausasaphes shiralee Naumann \& Reid (Bouček 1988; Naumann and Reid 1990). Therefore, should Asaphesinae prove monophyletic, this would suggest that at least one major switch in life-history mode has occurred in its evolution. Eunotinae contains a variety of parasitoids and egg predators of scale insects (Hemiptera: Coccoidea) occurring in all continents except Antarctica, although some have been reported from other hosts (Graham 1969; Bouček 1988; Bouček and Rasplus 1991). Here again, at least one switch from egg predation to parasitism has apparently occurred. The life history of many species in both subfamilies is largely unknown, and most species have not been placed in a phylogenetic analysis, whether morphological or molecular. Therefore, additional research would prove invaluable in providing a context and foundation for the elucidation of their evolutionary histories.

\section{Methods}

Fossil holotypes are deposited in the American Museum of Natural History, New York, USA (AMNH). Stereoscope photographs were taken using Leica Imaging System Software with a Z16 APO A microscope. Terminology follows that of Heraty et al. (2013), with some additional terms or usage following Gibson (1997) or Goulet and Huber (1993), and sculptural terms following Eady (1967). 


\section{Taxonomy}

Asaphesinae Burks \& Heraty new name Asaphini Ashmead, 1904: 327, junior homonym of Asaphidae Burmeister, 1843: 118 (Trilobita).

Type genus Asaphes Walker, 1834.

http://www.zoobank.org/urn:Isid:zoobank.org:act:DEB481C2-B0F6-4A59-8D108CC63A282D86

\section{Nomenclatural note}

The subfamily name Asaphinae Ashmead 1904 (originally the tribe Asaphini) is a junior homonym of the trilobite family Asaphidae Burmeister 1843: pg. 118, type genus Asaphus Brongniart. Even though these names were described at different family-group ranks, they are homonyms because all family-group names (superfamily to subtribe) compete for homonymy regardless of rank. The stem of the name (the genitive stem of the type genus) is what indicates homonymy of family groups (ICZN 1999: Article 53.1). In this case, the genitive stems are both Asaph- and both stems are correctly formed. No other familygroup name exists as a junior synonym of Asaphinae Ashmead, and therefore we propose the replacement name Asaphesinae n. $\mathbf{n}$. The two type generic names are not homonyms (ICZN 1999: Article 56.2).

Coriotela Burks \& Heraty n. gen. (Figure $1(\mathrm{a}-\mathrm{c})$

Type species: Coriotela lasallei Burks \& Heraty n. sp.

http://www.zoobank.org/urn:Isid:zoobank.org:act:FA0DE480-3731-47ED-A1E4-

D01566924A90

\section{Diagnosis}

Occipital carina (Figure 1(a): occ) present as a weak, uniform arch. Antenna with 1 anellus; toruli located above lower eye margin. Fore wing without speculum (uniformly setose). Prepectus bare. Frenal groove (Figure 1(a): frl) complete to frenal arms, indicated medially by row of distinct sculpture. First gastral tergum without long setae basally.

Description. Head with coriaceous sculpture. Antenna with 12 flagellomeres, including a small anellus, 7 funiculars, and 4 clavomeres (including terminal button) (Figure 1(b)). Toruli above lower eye margin, slightly below centre of face. Maxilla with 4 palpomeres, labium with 3 palpomeres. Occipital carina weakly indicated as a uniform arch, and without the median peak found in some Asaphesinae. Gena posteriorly carinate near mandibular base.

Mesosoma predominantly with coriaceous sculpture. Mesoscutum with complete notauli. Axillula slightly recessed relative to surrounding areas; frenum indicated by complete frenal groove. Prepectus bare. Fore wing without speculum, uniformly setose; parastigma with constriction and hyaline area immediately beyond one pair of placoid sensilla (Figure $1(\mathrm{c})$ ), marginal vein slightly longer than stigmal vein (when measured as indicated by Gibson 1997), slightly over half as long as postmarginal vein. Fore leg with 


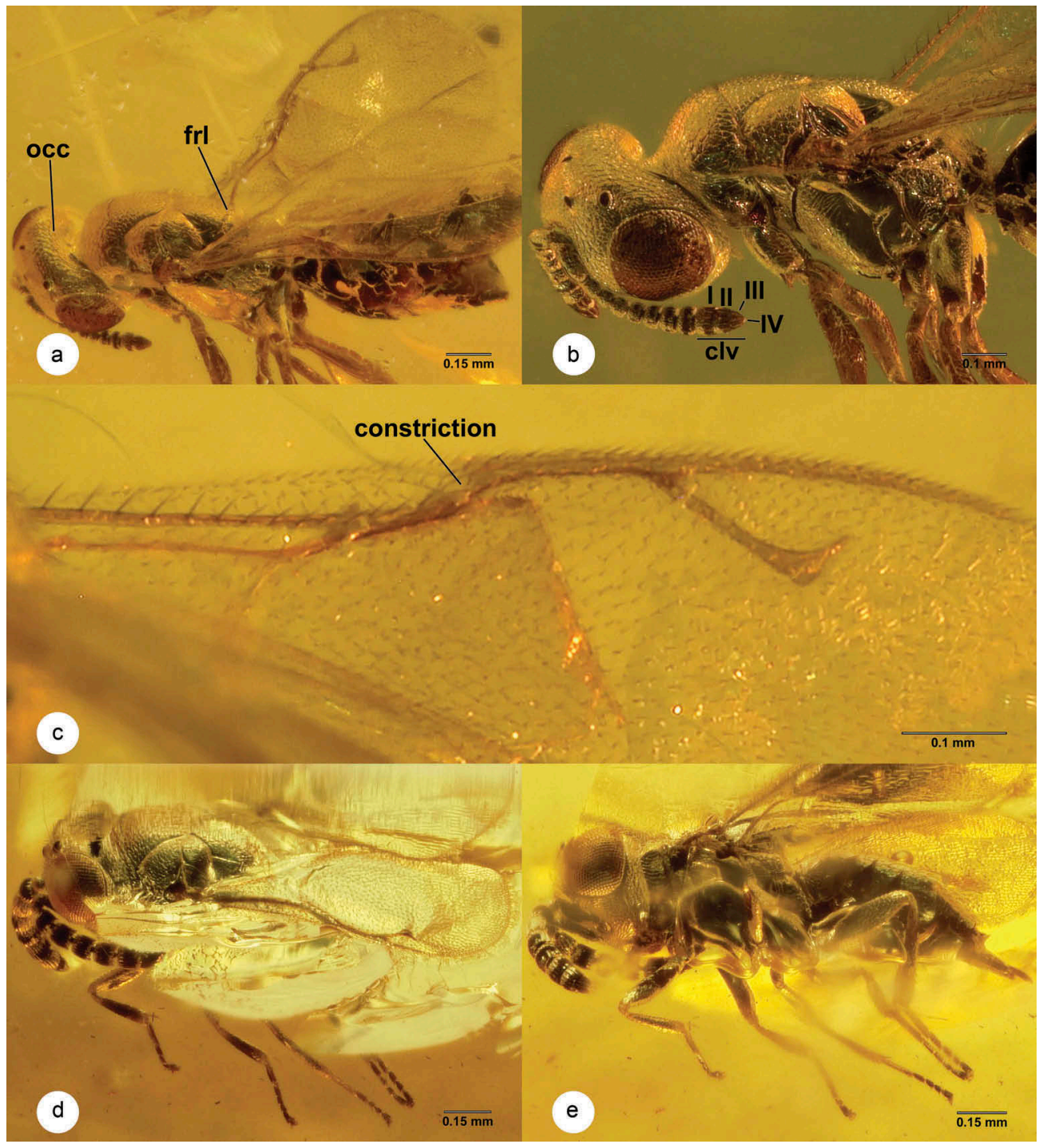

Figure 1. (a-c) Coriotela lasallei n. gen., n. sp. holotype female: (a) Body, dorso-lateral; (b) Head, mesosoma, and anterior part of metasomal, lateral, $\mathrm{frl}=$ frenal groove, occ $=$ occipital carina. (c) Fore wing, clv = clava, clavomeres numbered. (d,e) Butiokeras costae n. gen., n. sp. holotype male: (d) Body, dorso-lateral; (e) Body, ventro-lateral.

curved, stout, apically cleft fore tibial spur; basitarsal comb oblique, crossing basitarsal notch. Mid tibial spur not enlarged.

Metasoma. Petiole short but with strong carinae dorsally. Gaster dorsally convex; $\mathrm{Gt}_{1}$ without setae basally; $\mathrm{Gs}_{1}$ antecostal sulcus crossed by longitudinal carinae, anterior margin of sulcus strongly carinate. Hypopygium reaching to level of $\mathrm{Gt}_{6}$ midlength. $\mathrm{Mt}_{8+9}$ united as syntergum. 
Etymology. From the Latin words corium $=$ leather, and tela $=$ cloth. Intended to describe the coriaceous sculpture. Gender feminine.

Coriotela lasallei Burks \& Heraty n. sp. (Figure 1(a-c))

http://www.zoobank.org/urn:Isid:zoobank.org:act:0F193F45-CE1B-4A61A32F-BAE76F3A5900

Description. Female: Length $2.13 \mathrm{~mm}(\mathrm{n}=1)$.

Head. Scape not reaching level of median ocellus; pedicel subequal to combined length of F1-F3; flagellum with 1 anellus, 7 funiculars, and 4 clavomeres (including terminal button); anellus transverse, with short setae; funiculars progressively becoming broader, but not longer, apically; F2 about as long as broad; clava symmetrical. [mandibles closed and poorly visible, therefore teeth not counted]

Head with coriaceous to imbricate sculpture, with short setae; interantennal prominence present, acute dorsally. Toruli separated by about 1 torular diameter. Eyes subparallel, with extremely small setae that are hardly visible at $50 \times$ magnification. Clypeus short and broad. Labrum with frontal surface recessed, apically slightly concave. Malar sulcus present. Vertex rounded.

Mesosoma with short setae; dorsum coriaceous to imbricate. Pronotum long, broad, smoothly rounded anteriorly, uniformly sculptured. Upper mesepimeron slightly raised, broad recessed area partially crossing mesepimeron at transepimeral line; anterior margin of metapleural lateral area slightly overlapping mesepimeron. Fore wing with postmarginal vein slightly curved $1.82 \times$ stigmal vein length (including stigma), $1.4 \times$ marginal vein length; uncus long. Propodeum coarsely sculptured, with carinae near spiracle.

Metasoma length $1.6 \times$ metasoma width, $1.4 \times$ mesosoma length. Gastral terga of similar length, but $\mathrm{Gt}_{3}$ slightly shorter than the others. Hypopygium short, reaching only to $\mathrm{Gt}_{2}$.

\section{Material examined}

Holotype. Baltic amber inclusion: Eocene, Jens-Wilhelm Janzen coll., 2007 AMNH Ba-JWJ285. Photo also in Janzen 2002 (Figure 311). [1F\#, AMNH: UCRCENT00237910]. Deposited in AMNH.

Etymology. Named after John La Salle, who first introduced me (RAB) to the excitement of chalcidoid fossils.

Discussion. Coriotela is classified in Asaphesinae because of shared features with Hyperimerus and to some undescribed Neotropical genera, including antenna position and flagellomere shape and count (Shender et al. Figure 14), pronotum shape (Shender et al. Figure 19), and fore wing venation (Shender et al. Figure 21). Because Asaphesinae is not yet defined phylogenetically, the key features used for this placement are likely a mix of plesiomorphies and synapomorphies. Some defining features of the subfamily are relatively rare across Chalcidoidea, and therefore should be investigated as potential synapomorphies of the subfamily, including: metasomal petiole short but with strong sculpture (Figure 1(b)), gaster strongly sclerotised and rigid, fore wing venation with 
a short marginal vein relative to the stigmal and postmarginal veins, parastigma with a constriction (Figure 1(c): constriction). Other defining features of the group are more likely plesiomorphic or only very locally informative, but serve to eliminate some other taxa from consideration: antenna with 12 flagellomeres, occipital carina present, pronotum with a relatively long but anteriorly rounded collar, notauli complete, frenal groove indicated.

A suite of similar taxa in Pteromalidae s. I. can be eliminated from consideration for placement of $C$. lasallei as follows: Pteromalinae either exhibit a demarcation between the pronotal collar and pronotal neck, or the pronotum consists only of an essentially vertical neck, and pteromalines do not have all the other key features of $C$. lasallei in combination. The lack of absolute morphological distinction between Pteromalinae and other subfamilies of Pteromalidae s. I. has been discussed elsewhere (Graham 1969; Bouček 1988), but molecular data support a monophyletic Pteromalinae, inclusive of some non-pollinator fig wasps, that is separate from most other subfamilies of Pteromalidae sensu lato (Heraty et al. 2013). The genera of Pteromalinae most similar to C. lasallei and other Asaphesinae include Coruna Walker, Oricoruna Bouček, Sphegipterosema Girault, and Yanchepia Bouček. However, each of these genera lacks key features mentioned in the diagnosis of $C$. lasallei and instead possess gestalt features that place them in particular subgroups of Pteromalinae (Graham 1969; Bouček 1988; Bouček and Rasplus 1991; Bouček and Heydon 1997).

A few subgroups of Pteromalidae s. I. are somewhat similar to C. lasallei, and are discussed here to help explain its subfamily placement. Austrosystasinae differs from all Asaphesinae in features of gestalt: a more arched and stout body, and a much larger metacoxa (Bouček 1988, figure 550). Diparinae usually possess an occipital carina, but other typically diparine features such as the cercal brush (Desjardins 2007, figure 17) and gestalt features of metacoxal sculpture and of the fore wing are absent from C. lasallei. Herbertiinae are part of a set of pteromalid taxa that differ by having fewer than 12 antennal flagellomeres. Keiraninae are similar to C. lasallei, but have a more distinct pronotal collar that is set off from the pronotal neck by a stronger change in curvature (Bouček 1988, figure 475). Distinction of Asaphesinae from Keiraninae, when limited to features typically visible on an amber fossil, relies on vague gestalt features. However, preliminary genetic data (Heraty et al. unpublished) support separation of extant species of these two taxa into widely separated clades in the superfamily phylogeny. Melanosomellini (in Ormocerinae) contains a few genera with an occipital carina, but these have a smaller axillula and a strong mesoscutellar rim, and they have a broader, less sculptured petiole (e.g. Bouček and Heydon 1997, figure 80). Parasaphodinae differ in having strongly advanced axillae (Bouček 1988, figure 629).

Within Asaphesinae, C. lasallei is distinguished by a combination of features mentioned in the diagnosis of the genus. Asaphes differs chiefly in having two or more basal flagellomeres lacking multiporous plate sensilla (= anelli) and toruli situated very near the mouth margin (Bouček and Rasplus 1991; Bouček and Heydon 1997, figure 84; Gibson and Vikberg 1998). Ausasaphes Bouček possesses a dorsally indistinct frenal groove and a longer petiole (Bouček 1988, figure 631). Enoggera Girault possesses a very differently shaped head, mesosoma, and metasoma, and also differs in having more anelliform basal flagellomeres and a much larger $\mathrm{Gt}_{1}$ (Bouček 1988). Hyperimerus 
Girault differs in that its prepectus and $\mathrm{Gt}_{1}$ basally are strongly setose (Gibson and Vikberg 1998; Schender et al. 2014 figures 11-12). The chiefly coriaceous sculpture of Coriotela is also distinctive within the subfamily, present mainly in some undescribed Neotropical taxa (Burks unpub.).

\title{
Asaphesinae: taxonomic changes
}

The type specimen of Desantisiana jujuyensis Neder de Román, described in Asaphinae (Neder de Román 1999), was examined and found to belong to Notoglyptus Masi, which is classified in the tribe Sphegigastrini of Pteromalidae sensu stricto. Because D. jujuyensis is the type and only species of Desantisiana n. syn., this name becomes a junior synonym of Notoglyptus. We suggest that comparison of Notoglyptus jujuyensis (Neder de Román) n. comb. with Neotropical species described by Heydon (1989) may result in synonymy of the species.

\section{Eunotinae: Eunotini}

\author{
Butiokeras Burks \& Heraty n. gen. (Figure $1(\mathrm{~d}, \mathrm{e})$ ) \\ Type species: Butiokeras costae n. sp. \\ http://www.zoobank.org/urn:Isid:zoobank.org:act:129BA554-88A2-4B60-A619- \\ 886B30AE7697
}

\section{Diagnosis}

Antennal flagellum in male with 1 anellus, 4 funiculars, and 3 clavomeres; all except the anellus with a row of many raised multiporous plate sensilla that span the length of their respective segment. Vertexal carina absent. Mesoscutum and mesoscutellum with fineraised reticulate sculpture. Fore wing densely setose, without speculum. Gaster not rigidly convex but apparently with more flexible terga; first gastral tergum short, not more than a third total gastral length, with lateral incision.

Description. Male. Head finely reticulate, with large subcircular eyes that are well separated and with ventral divergent medial margins, and gena short dorsally (thus head of shape typical for Eunotus Walker). Eye reaching posterior margin of head dorsally; lateral ocelli not reaching posterior margin of vertex. Malar sulcus present. Clypeus weakly convex, with subapical groove near ventral margin (as in Eunotus); labrum present and exposed, short and flap-like. Antennal flagellum with 1 very short anellus, 4 funiculars, 3 clavomeres, with each funicular and clavomere with raised multiporous plate sensilla extending the length of their flagellomere; flagellar setae short and appressed to their segment, therefore inconspicuous. Vertex somewhat abrupt posteriorly, but rounded and without vertexal carina.

Mesosoma dorsally finely reticulate. Pronotum without collar. Mesoscutum and mesoscutellum densely covered with short setae. Axilla slightly, but not strongly, advanced. Axillular sulcus carinate laterally. Fore wing entirely densely setose, without speculum. Prepectus subtriangular, reticulate. Mesopleural area with dorsal pit; mesepimeron elevated and nearly smooth. Marginal vein slightly more than twice stigmal vein 
length; postmarginal vein longer than stigmal vein but shorter than marginal vein; uncus long. Legs each with 5 tarsomeres; fore tibial spur stout and curved.

Metasoma about as long as head plus mesosoma; terga not rigidly convex but apparently with more flexible terga. First gastral tergum short, less than a third total gastral length; with lateral incision of the type frequently found in other chalcidoids (e.g. Perilampidae) but not found in other Eunotini. Male genitalia with volsellar digiti and parameres.

Etymology. After the Greek words Butio = barrel, and кźpac = horn. Refers to the multiporous plate sensilla of the antenna. Gender neuter.

Butiokeras costae n. sp. (Figure 1(d,e))

http://www.zoobank.org/urn:Isid:zoobank.org:act:E96B18F5-E685-40F8-A9AB68CC459E907C

Description. Male: Length $1.34 \mathrm{~mm}(\mathrm{n}=1)$. Most important features reported in the generic description, but a few presumably specific features mentioned here.

Head. Flagellomeres slightly broader than long, each with 1 row of multiporous plate sensilla [mentioned here because Eunotus species vary in the number or rows per segment].

Mesosoma very weakly arched anteriorly and posteriorly, but flat at scutoscutellar sulcus. Propodeum laterally with a strongly sculptured elevation. First tarsomere of each leg almost as long as the others combined.

\section{Material examined}

Baltic amber inclusion: Eocene, Jens-Wilhelm Janzen coll. [1M\#, AMNH: UCRCENT305754]. Deposited in AMNH. Small fractures near the wings block view of some structures.

Etymology. After the Latin noun costa, meaning rib. Genitive case.

Discussion. Females are unknown but presumably are similar to the known male except for the antenna and gaster. Butiokeras is classified in Eunotini, near Eunotus, because it shares features of the male flagellum and fore wing with extant species of Eunotus. The flagellomeres in males are distinctive, each with one or two rows of multiporous plate sensilla that give the appearance of ribs because they are conspicuously elevated and in total extend about the same length as their respective flagellomeres. These antennal features are best known from the Eunotus kocoureki Bouček species group, which is also defined by the presence of three mandibular teeth instead of two (Bouček 1972). Placement in the $E$. kocoureki species group was considered, but rejected because Butiokeras costae lacks a vertexal carina and possesses a short $\mathrm{Gt}_{1}$. Either of these character states would be unique within Eunotus, and the occurrence of both together and consideration of the fossil's age suggest that Butiokeras is best treated as a distinct genus.

Other genera of Eunotini are distinctly different from Butiokeras. Epicopterus Westwood and Mesopeltita Ghesquière differ in having a strong incision in the fore wing near the marginal vein base. Scutellista Motschulsky is known for its elongate mesoscutellum which 
typically extends dorsally over the metanotum, propodeum, and part of the gaster. Cephaleta Motschulsky and the apparently closely related Cavitas Xiao \& Huang also have a relatively short $\mathrm{Gt}_{1}$, but they also have a relatively smooth and glossy mesoscutum and mesoscutellum instead of the fine raised sculpture present in Eunotus (Xiao \& Huang 2001) and Butiokeras.

\section{Eunotinae: taxonomic changes}

Three other tribes may be correctly placed in Eunotinae: Idiopororini, Moranilini, and Tomocerodini, all distinctly different from Eunotini and potentially not forming a monophyletic group with it (Munro et al. 2011). Calyconotiscini was described by Narendran et al. (2012) in Eunotinae accommodate a species reared from galls of Cecidomyiidae. Examination of this species indicates that Calyconotiscus frontofasciatus Narendran \& Saleem is a yellowish member of Pireninae that is otherwise not much different from Gastrancistrus Westwood, a conclusion upheld by its host relationships. We transfer Calyconotiscus Narendran \& Saleem to Pireninae and abolish the tribe Calyconotiscini n. syn., because it likely does not represent a particularly informative group within Pireninae.

\section{Discussion}

An at least Eocene age for Asaphesinae and Eunotini is helpful for addressing some of the problems of pteromalid phylogenetics, indicating that some variation within Pteromalidae sensu lato is relatively old compared with that of already described families. Among extant families, only Mymaridae and Rotoitidae are definitively known from any fossils older than Eocene (Poinar and Huber 2011; Gumovsky et al. 2018). While other families such as Eulophidae and Trichogrammatidae were reported from putatively Cretaceous Ethiopian amber fossils by Schmidt et al. (2010), later data (Perrichot et al. 2016, 2018) have shown Ethiopian amber to be Early Miocene in origin (16-23 Ma).

Therefore, it is possible that Asaphesinae and Eunotini, from at least the Eocene, are about as old as most other chalcidoid families. This possibility is upheld by molecular data, which place Asaphesinae and Eunotini in scattered positions among other Pteromalidae sensu lato and relatively well-sclerotised Chalcidoidea, such as Eucharitidae, Ormyridae, Perilampidae, and Torymidae (Heraty et al. 2013). Given that informative value of family groups would likely be damaged by lumping so many families into a broader Pteromalidae sensu lato, this suggests that some subfamilies of Pteromalidae may be better removed from Pteromalidae sensu stricto. This does not address the problem of family delimitation however, and not enough information exists in the fossil record to do so. Any change in rank or family placement for Asaphesinae or Eunotini would be premature without re-examination and equal-handed treatment of all other chalcidoid taxa using molecular and morphological data.

\section{Acknowledgements}

We thank David Grimaldi (AMNH) for loan of the amber specimens. Mircea Mitroiu provided valuable feedback on our proposed placement of Calyconotiscus, and we thank him, Lars Krogmann (SMNH), and Gary Gibson (CNC) for valuable comments on pteromalid systematics. 
The John Heraty Laboratory and Lars Krogmann provided valuable comments on the manuscript. Daniel Aquino (Museo de la Plata, Argentina) provided valuable photographs of Desantisiana jujuyensis. Funding for this research was provided by grant NSF-DEB 1555808 and UCR Hatch project funding to $\mathrm{JMH}$.

\section{Disclosure statement}

No potential conflict of interest was reported by the authors.

\section{Funding}

This work was supported by the National Science Foundation [NSF-DEB 1555808].

\section{References}

Ashmead WH. 1904. Classification of the chalcid flies of the superfamily Chalcidoidea, with descriptions of new species in the Carnegie Museum, collected in South America by Herbert H. Smith. Memoirs Carnegie Museum. 1:i-xi, 225-551, 39 pls.

Bläser M, Krogmann L, Peters RS. 2015. Two new fossil genera and species of Cerocephalinae (Hymenoptera, Chalcidoidea, Pteromalidae), including the first record from the Eocene. ZooKeys. 545:89-100. doi:10.3897/zookeys.545.6470.

Bouček Z. 1972. On European Pteromalidae (Hymenoptera): a revision of Cleonymus, Eunotus and Spaniopus, with descriptions of new genera and species. Bull Br Museum (Nat History) Entomol. 27:265-315.

Bouček Z. 1988. Australasian Chalcidoidea (Hymenoptera). A biosystematic revision of genera of fourteen families, with a reclassification of species. Wallingford (UK): CAB International; p. 832.

Bouček Z, Heydon SL. 1997. Chapter 17, Pteromalidae. In: Gibson GAP, Huber JT, Woolley JB, editors. Annotated keys to the genera of Nearctic Chalcidoidea (Hymenoptera). Ottawa: NRC Research Press; p. 541-692.

Bouček Z, Rasplus J-Y. 1991. Illustrated key to West-Palearctic Pteromalidae. Paris: INRA; p. 140.

Burks RA, Heraty JM, Pinto JD, Grimaldi D. 2015. Small but not ephemeral: newly discovered species of Aphelinidae and Trichogrammatidae (Insecta: Hymenoptera: Chalcidoidea) from Eocene amber. Syst Entomol. 40:592-605. doi:10.1111/syen.12124.

Burks RA, Krogmann L, Heraty JM. 2018. Simultaneous discovery and taxonomic placement of new extant and fossil genera of Herbertiinae (Hymenoptera: Chalcidoidea: Pteromalidae). Insect Syst Div. 2(5):1-8. doi:10.1093/isd/ixy012.

Burmeister H. 1843. Die organisation der Trilobiten, aus ihren lebenden Verwandten entwickelt; nebst einer systematischen Uebersicht aller zeither beschriebenen Arten. Berlin: Georg Reimer; p. 147,6 pls.

Campbell B, Heraty J, Rasplus J-Y, Chan K, Steffen-Campbell J, Babcock C. 2000. Molecular systematics of the Chalcidoidea using 28S-D2 rDNA. In: Austin AD, Dowton M, editors. Hymenoptera evolution, biodiversity and biological control. Collingwood (Australia): CSIRO Publishing; p. $59-73$.

Desjardins CA. 2007. Phylogenetics and classification of the world genera of Diparinae (Hymenoptera: Pteromalidae). Zootaxa. 1647:1-88. doi:10.11646/zootaxa.1647.1.1.

Eady RD. 1967. Some illustrations of microsculpture in the Hymenoptera. Proc R Entomol Soc of London (A). 43:66-72. doi:10.1111/j.1365-3032.1968.tb01029.x.

Engel MS, McKellar RC, Huber JT. 2013. A fossil species of the primitive mymarid genus Borneomymar (Hymenoptera: Mymaridae) in Eocene Baltic amber. Novitates Paleoentomologicae. 5:1-8. 
Gibson GAP. 1997. Chapter 2, Morphology and terminology. In: Gibson GAP, Huber JT, Woolley JB, editors. Annotated keys to the genera of Nearctic Chalcidoidea (Hymenoptera). Ottawa: NRC Research Press; p. 16-44.

Gibson GAP. 2008. Description of Leptoomus janzeni, n. gen. and n. sp. (Hymenoptera: Chalcidoidea) from Baltic amber, and discussion of its relationships and classification relative to Eupelmidae, Tanaostigmatidae and Encyrtidae. Zootaxa. 1730:1-26. doi:10.11646/zootaxa.1730.1.1.

Gibson GAP. 2009. Description of three new genera and four new species of Neanastatinae (Hymenoptera, Eupelmidae) from Baltic amber, with discussion of their relationships to extant taxa. ZooKeys. 20:175-214. doi:10.3897/zookeys.20.161.

Gibson GAP, Heraty JM, Woolley JB. 1999. Phylogenetics and classification of Chalcidoidea and Mymarommatoidea - a review of current concepts (Hymenoptera, Apocrita). Zool Scr. 28:87-124. doi:10.1046/j.1463-6409.1999.00016.x.

Gibson GAP, Vikberg V. 1998. The species of Asaphes Walker from America North of Mexico, with remarks on extralimital distributions and taxa (Hymenoptera: Chalcidoidea, Pteromalidae). J Hymenoptera Res. 7(2):209-256.

Goulet H, Huber JT. 1993. Hymenoptera of the world: an identification guide to families. Ottawa: Agriculture Canada; p. 668.

Graham MWRDV. 1969. The Pteromalidae of north-western Europe (Hymenoptera: Chalcidoidea). Bull Br Museum (Nat History) (Entomol) Suppl. 16:908, 686 figures.

Gumovsky A, Perkovsky E, Rasnitsyn A. 2018. Laurasian ancestors and "Gondwanan" descendants of Rotoitidae (Hymenoptera: Chalcidoidea): what a review of Late Cretaceous Baeomorpha revealed. Cretaceous Res. 84:286-322. doi:10.1016/j.cretres.2017.10.027.

Heraty J, Darling DC. 2009. Fossil Eucharitidae and Perilampidae (Hymenoptera: Chalcidoidea) from Baltic amber. Zootaxa. 2306:1-16. doi:10.11646/zootaxa.2306.1.1.

Heraty JM, Burks RA, Cruaud A, Gibson GA, Liljeblad J, Munro J, Rasplus J-Y, Delvare G, Janšta P, Gumovsky A, et al. 2013. A phylogenetic analysis of the megadiverse Chalcidoidea (Hymenoptera). Cladistics. 29:466-542. doi:10.1111/cla.12006.

Heydon SL. 1989. A review of the world species of Notoglyptus Masi (Hymenoptera: Pteromalidae). Proc Entomol Soc Washington. 91:112-123.

ICZN (International Commission on Zoological Nomenclature). 1999. International code of zoological nomenclature. 4th ed. London: International Trust for Zoological Nomenclature; p. xxix + 306.

Janzen JW. 2002. Arthropods in Baltic Amber. Halle (Saale): Ampyx-Verlag; p. 167.

Krogmann L, Vilhelmsen L. 2006. Phylogenetic implications of the mesosomal skeleton in Chalcidoidea (Hymenoptera, Apocrita) - tree searches in a jungle of homoplasy. Invertebr Syst. 20:615-674. doi:10.1071/IS06012.

Munro JB, Heraty JM, Burks RA, Hawks D, Mottern J, Cruaud A, Rasplus J-Y, Janšta P. 2011. A molecular phylogeny of the Chalcidoidea (Hymenoptera). PLoS One. 6:1-27. doi:10.1371/ journal.pone.0027023.

Narendran TC, Saleem UKA, Nasser M. 2012. Calyconotiscini (Hymenoptera: Pteromalidae: Eunotinae) an interesting new tribe and a new genus from India with comments on the placement of tribe Eriaporini and a key to tribes of Eunotinae. Biosystematica. 6(1):5-12.

Naumann ID, Reid CAM. 1990. Ausasaphes shiralee sp.n. (Hymenoptera: Pteromalidae: Asaphinae), a brachypterous wasp phoretic on a flightless chrysomelid beetle (Coleoptera: Chrysomelidae). Journal of the Australian Entomological Society 29: 319-325.

Neder de Román LE. 1999. Nuevo género y especie de Asaphinae (Hymenoptera: Pteromalidae) de la prepuna de la Argentina. Revista De La Sociedad Entomológica Argentina. 58 (3-4):129-132.

Noyes JS. 1990. A word on chalcidoid classification. Chalcid Forum. 13:6-7.

Noyes JS. 2019. Universal Chalcidoidea database. [accessed 2019 Mar 21]. http://www.nhm.ac.uk/ chalcidoids.

Perrichot V, Boudinot B, Cole J, Delhaye-Prat V, Esnault J, Goldman Y, Nohra YA, Schmidt AR. 2016. African fossiliferous amber: a review. 7th International Conference on fossil insects, arthropods 
and amber. In: Penney D, Ross AJ, editors. Fossils x3, Edinburgh 2016, Abstracts. Edinburgh: Siri Scientific Press; p. 41.

Perrichot V, Boudinot B, Chény C, Cole J, Jeanneau L, Schmidt A, Szwedo J, Wang B. 2018. The age and paleobiota of Ethiopian amber revisited. The Fossil Week Abstract Book. IPC5-5th International Palaeontological Congress; Paris, France. p. 23.

Poinar G Jr., Huber JT. 2011. A new genus of fossil Mymaridae (Hymenoptera) from Cretaceous amber and key to Cretaceous mymarid genera. ZooKeys. 130:461-472. doi:10.3897/ zookeys.130.1241.

Ritzkowski S. 1997. K-Ar-altersbestimmungen der bernsteinführenden sedimente des Samlandes (Paläogen, Bezirk Kaliningrad). Metalla (Sonderheft). 66:19-23.

Schender D, Katz K, Gates MW. 2014. Review of Hyperimerus (Pteromalidae: Asaphinae) in North America, with redescription of Hyperimerus corvus (Girault). Proc Entomol Soc Washington. 116 (4):408-420. doi:10.4289/0013-8797.116.4.408.

Schmidt AR, Perrichot V, Svojtka M, Anderson KB, Belete KH, Bussert R, Dörfelt H, Jancke S, Mohr B, Mohrmann E, et al. 2010. Cretaceous African life captured in amber. Proc Natl Acad Sci. 107:7329-7334. doi:10.1073/pnas.1000948107.

Walker F. 1834. Monographia Chalciditum. Entomol Mag. 2:148-179.

Xiao H, Huang D-W. 2001. A review of Eunotinae (Hymenoptera: Chalcidoidea: Pteromalidae) from China. J Nat History. 35:1587-1605. doi:10.1080/002229301317092342. 